\title{
The Effect of Lectin from Taro Tuber (Colocasia antiquorum) Given by Force-Feeding on the Growth of Mice
}

\author{
Young-Joo SeO, ${ }^{1}$ Satsuki UnE, ${ }^{2}$ Ikuyo TsuKamoto, ${ }^{3}$ \\ and Masamitsu MIYOSHI ${ }^{3}$ \\ ${ }^{1}$ Graduate Division of Human Culture (Doctoral Degree Program), \\ Nara Women's University, Nara 630, Japan \\ ${ }^{2}$ Laboratory of Food Science and Nutrition, Mimasaka Women's University, \\ Tsuyama, Okayama 708, Japan \\ ${ }^{3}$ Laboratory of Nutritional Chemistry, Department of Food Science \\ and Nutrition, Nara Women's University, Nara 630, Japan
}

(Received July 6, 1989)

Summary In earlier experiments in our laboratory, a lectin from the Kintoki bean (Phaseolus vulgaris) was found to have not only erythrocyte agglutinating activity but also toxicities for mice and rats, including growth inhibitory activity and even lethal activity. A number of studies on legume lectins have been carried out in other laboratories as well. But relatively little attention has been paid to lectins from non-leguminous foods. In the present study, we chose Taro tuber as a source of non-leguminous lectins and prepared two types of Taro tuber lectin. One was crude lectin precipitated with ammonium sulfate from the aqueous extract and the other was pure lectin isolated as we described previously. The two were compared with regards to the antinutritional functions in mice. The daily doses were $100 \mathrm{mg}$ for either intact or autoclaved crude lectin, which was a maximum amount available to give to mice in $1 \mathrm{ml}$, and $30 \mathrm{mg}$ for the pure lectin which was equivalent to $100 \mathrm{mg}$ of the crude lectin in hemagglutinating activity. Control mice were given $1 \mathrm{ml}$ of water and the experiment was conducted for 6 days. Growth retardation was found in the mice given either lectin, but no significant difference was found in the weight increase between the control group and the autoclaved lectin group. For 3 days during the experimental period, physical activity was measured as an index of vigor of mice. The activities of the crude lectin and the pure lectin groups leveled down to 62.9 and $64.2 \%$ of that of the control group, respectively. No apparent difference was observed in the tissue weights among the groups at the end of the experiment. Protein efficient ratio (PER) values indicated worse efficiency of protein utilization in the lectin groups. Enzyme activities of

${ }^{1}$ 徐 栄珠, ${ }^{2}$ 畦 五月, ${ }^{3}$ 塚本幾代, ${ }^{3}$ 三好正満 
sucrase, leucine aminopeptidase, and particularly of alkaline phosphatase were lower in the small intestine of the experimental groups. These results indicate that Taro tuber lectin has toxicity inhibiting regular biological functions in the intestine of mice, leading to growth retardation. Since Taro tuber lectin is more resistant to heat treatment than legume lectins, the present results suggest a need for care in cooking Taro tuber.

Key Words Taro tuber lectin, antinutrient, physical activity, toxicity, alkaline phosphatase, sucrase, leucine aminopeptidase

Many foods are known to contain specific carbohydrate-binding proteins called lectin (1). It occurs in a wide variety of plants, in bacteria and other microorganisms, and in invertebrates and vertebrates. This fact means that we daily ingest various types of lectin probably in larger amounts than estimated hitherto. Some of these lectins have been purified and characterized in detail $(2,3)$.

The proteins of lectin have potent biological effects mediated via high-affinity binding to specific carbohydrate residues on the surface of cells. They initiate a number of activities on cells, such as blood-cell agglutination, tuber-cell agglutination, stimulation of lymphocyte proliferation, etc. (4). From the viewpoints of nutritional science and food chemistry, lectin in general has been characterized as a component of foods which causes severe damages to the digestive tract (5), leading to growth retardation (6) and even death for experimental animals (7).

In our laboratory, we have directed much attention to a lectin contained in the Kintoki bean (Phaseolus vulgaris) and have confirmed that the purified lectin of Kintoki beans impaired the growth of mice to an extent directly proportional to its dose (8). It was also suggested that Kintoki bean lectin was chiefly responsible for the observed toxicity. Early death of weanling rats was observed when they were fed diets prepared with soy beans, field beans, or winged beans (9). Most of the bean lectins, however, lose their toxicities on heat treatment and thereby pose no practical danger to human beings who take cooked beans. But some lectins of other origins are relatively resistant to heat treatment. Taro tuber lectin can be classified into the latter (10). Therefore, it seems important to examine the nutritional properties of Taro tuber lectin apart from legume lectins.

We previously reported that Taro tuber contains a lectin toxic to mice when injected intraperitoneally and we characterized its chemical and physical properties $(10,11)$. In this study, we examined the oral toxic effects of Taro tuber lectin on mice by analyzing the relationships among changes, due to lectin intake, in body weight, food consumption, physical activity, tissue weight, and villus enzyme activity in the small intestine.

\section{MATERIALS AND METHODS}

Taro tuber (Colocasia antiquorum) was purchased at a market in Nara. The 
lectin was purified according to our previous method (10). Its hemagglutinating activity (HA) was assayed with a microtiter plate by the serial dilution technique using $1 \%$ red blood cells of mice (12) and its lethal activity (LA) was tested by intraperitoneal injection into mouse.

Experiment 1. Male mice of ddY strain, weighing about $10 \mathrm{~g}$, were obtained from Shizudokyo, Hamamatsu, Shizuoka, Japan. They were housed in wire-mesh cages in a room kept at $24 \pm 1^{\circ} \mathrm{C}$ and with light automatically regulated to provide 12-h light and dark periods, respectively. The mice were fed an albumin-based stock-diet. The composition of the basal diet was as follows: albumin, $10 \mathrm{~g}$; wheat starch, $63 \mathrm{~g}$; cellulose powder, $8 \mathrm{~g}$; soybean oil, $6 \mathrm{~g}$; McCollum mineral mixture, 6 $\mathrm{g}$; sugar, $5 \mathrm{~g}$; and Harper's vitamin mixture, $2 \mathrm{~g}$. They were weighed and given $1 \mathrm{ml}$ of water by use of a stomach tube around 13:00. Then the mice were fed the basal diet ad libitum until 9:00 of the following day. After the preliminary 5- to 7-day period of force-feeding with a stomach tube, the mice of about $15 \mathrm{~g}$ body weight were divided into one control group and three experimental groups of five mice each. The control group was given $1 \mathrm{ml}$ of water at 13:00 daily for 6 days with a stomach tube. Each experimental group was given either $100 \mathrm{mg}$ of crude lectin or $100 \mathrm{mg}$ of autoclaved crude lectin or $30 \mathrm{mg}$ of pure lectin dissolved in $1 \mathrm{ml}$ of water. These were given by stomach-feeding at 13:00 daily for the same 6 days. After the administration of either water or one of the lectins, the mice were fed the basic diet ad libitum. During those 6 days, the body weight and the food consumption were recorded every day just before the intubation. At the end of the experimental period, the mice were killed, and the livers, pancreases, spleens, and kidneys were excised and weighed immediately.

Experiment 2. For three days during the above force-feeding period, physical activities of the control and experimental rats were estimated with Animex III, an apparatus for measuring the activities of laboratory animals (Shimadzu Co., Kyoto). The counts representing degrees of physical activity were averaged every $2 \mathrm{~h}$ per day for each mouse.

Experiment 3. Intestinal alkaline phosphatase, maltase, sucrase, and leucine aminopeptidase (LAPse) are localized in the brush border membrane of the small intestine (13) and can be recovered in the microsomal fraction in the absence of a chelating agent (14). This experiment was performed to examine the in vivo effects of Taro tuber lectin on the activities of three intestinal enzymes.

The intestine of each mouse was excised at the end of the stomach-feeding period of experiment 1. It was divided into two sections of $15 \mathrm{~cm}$ length from the pylorus to distal intestine. Each segment, including the muscle layer, was split longitudinally after the contents had been rinsed out with cold phosphate-buffered saline (PBS). And then, it was homogenized in cold PBS with a Teflon-glass homogenizer. The homogenate was centrifuged at $1,000 \mathrm{rpm}$ for $10 \mathrm{~min}$ at $5^{\circ} \mathrm{C}$. The supernatant was used for the determination of protein and enzyme activity in the small intestine. The protein content was determined by the method of Lowry et al. (15). Alkaline phosphatase activity was determined by the method of Kind 
and King (16). Sucrase activity was measured by the method of Dahlquvist (17). Leucine aminopeptidase activity was estimated by the method of Goldbarg and Rutenburg (18).

Statistical analysis. Statistical analysis was done by the least significant difference calculated according to the method described by Snedector and Cochran (19).

\section{RESULTS AND DISCUSSION}

Before having been used for oral administration, Taro tuber lectin was tested with regard to its HA. The isolated protein showed HA at a concentration higher than $61 \mu \mathrm{g} / \mathrm{ml}$ (crude lectin) or $21 \mu \mathrm{g} / \mathrm{ml}$ (pure lectin) in the suspension of $1 \%$ mouse erythrocyte, indicating that the pure lectin of Taro tuber had HA that was about three times stronger than the HA of crude lectin. Therefore, we decided that the crude lectin should be administered in about a threefold larger quantity than the pure lectin to obtain a similar degree of toxicity in the following experiments.

As shown in Table 1, three groups of experimental mice on the basal albumin diet were daily administered by stomach feeding either $100 \mathrm{mg}$ of autoclaved crude lectin or $100 \mathrm{mg}$ of the crude lectin or $30 \mathrm{mg}$ of the pure lectin dissolved in $1 \mathrm{ml}$ of distilled water. One group of control mice received $1 \mathrm{ml}$ of water. The mice given either of the intact Taro tuber lectins showed growth inhibition, although the degree of the retardation was not large compared with that observed in the case of Kintoki bean lectin. Increase in the body weight of the experimental mice was reduced to about $60 \%$ (pure lectin) and $70 \%$ (crude lectin) compared to that of the control mice. The average food intakes per day were $6.7,6.5,5.5$, and $5.9 \mathrm{~g}$, and

Table 1. Effects of Taro tuber lections on the growth of mice.

\begin{tabular}{|c|c|c|c|c|}
\hline & Control & $\begin{array}{l}\text { Autoclaved } \\
\text { crude lectin }\end{array}$ & $\begin{array}{l}\text { Crude } \\
\text { lectin }\end{array}$ & $\begin{array}{l}\text { Pure } \\
\text { lectin }\end{array}$ \\
\hline $\begin{array}{l}\text { Amount given } \\
\text { (mg/day) }\end{array}$ & - & 100 & 100 & 30 \\
\hline $\begin{array}{l}\text { Initial body wt. } \\
\text { (g) }\end{array}$ & $17.7 \pm 0.27$ & $17.7 \pm 0.31$ & $17.5 \pm 0.18$ & $16.9 \pm 0.44$ \\
\hline $\begin{array}{l}\text { Change in body wt } \\
\text { ( } \mathrm{g} / 6 \text { days) }\end{array}$ & $9.7 \pm 0.61$ & $9.2 \pm 0.54$ & $5.7 \pm 0.25^{*}$ & $6.8 \pm 0.66^{*}$ \\
\hline (\% to control) & 100 & 94.9 & $58.8^{*}$ & $69.4^{*}$ \\
\hline $\begin{array}{l}\text { Food intake } \\
\text { (g/day) }\end{array}$ & $6.7 \pm 0.62$ & $6.5 \pm 0.54$ & $5.5 \pm 0.88^{*}$ & $5.9 \pm 0.78^{*}$ \\
\hline PER & 2.41 & 2.36 & $1.73^{*}$ & $1.92^{*}$ \\
\hline $\begin{array}{l}\text { Physical activity } \\
\text { (counts } 22 \mathrm{~h} \text { ) } \\
\text { (\% to control) }\end{array}$ & $\begin{array}{r}7,658 \\
100\end{array}$ & - & $\begin{array}{r}4,817^{*} \\
62^{*}\end{array}$ & $\begin{array}{r}5,459^{*} \\
64^{*}\end{array}$ \\
\hline
\end{tabular}

Means \pm SD $(n=6) . *$ Significantly different from control group, $p<0.05$. 
the protein efficient ratios (PER) were 2.41, 2.36, 1.73, and 1.92, in the order of the groups of water, autoclaved crude lectin, crude lectin, and pure lectin (Table 1). Statistical differences were found in the growth rate, food intake, and PER between the control and the intact lectin groups. In view of the growth retardation of the experimental mice, Taro tuber lectin seems to have some antinutritional function when it is given directly into the stomach. There was no clear difference in the degree of toxicity between the crude and pure lectins as long as the amount administered was maintained as in the present experiment. Judging from the fact that the pure lectin used in this study was three times stronger in HA than the crude lectin as mentioned above, it seems reasonable that the oral toxic effects of $100 \mathrm{mg}$ of the crude lectin and $30 \mathrm{mg}$ of the pure lectin should be equivalent to each other as shown in Table 1.

Figure 1 shows apparent differences in the physical activities between the control and experimental mice. The physical activities are expressed at 2 -h intervals as average counts of 3-day measurement. The percent of each $2-\mathrm{h}$ count to the total count of the control group, which was taken as $100 \%$, was plotted on the graph. The total physical activities, in terms of the total daily counts, of the two experimental groups fall off to 62.9 and $64.3 \%$ of that of the control group in the order of the crude lectin and pure lectin groups, respectively. There is no evident difference in activity between the crude and pure lectin groups.

Table 1 summarizes the toxic effects of Taro tuber lectin on body weight change, food intake, physical activity, and PER. In contrast to the control mice, the experimental mice showed slower growth rates and had neither sufficient food intake nor physical activity. PER was also considerably lowered in the experimental groups. The apparent syndromes visually observed in the experimental mice were a bad coat of hair and greatly reduced motion. In the paper describing the toxicity to rats orally given a kidney bean lectin, Pusztai et al. reported that a small

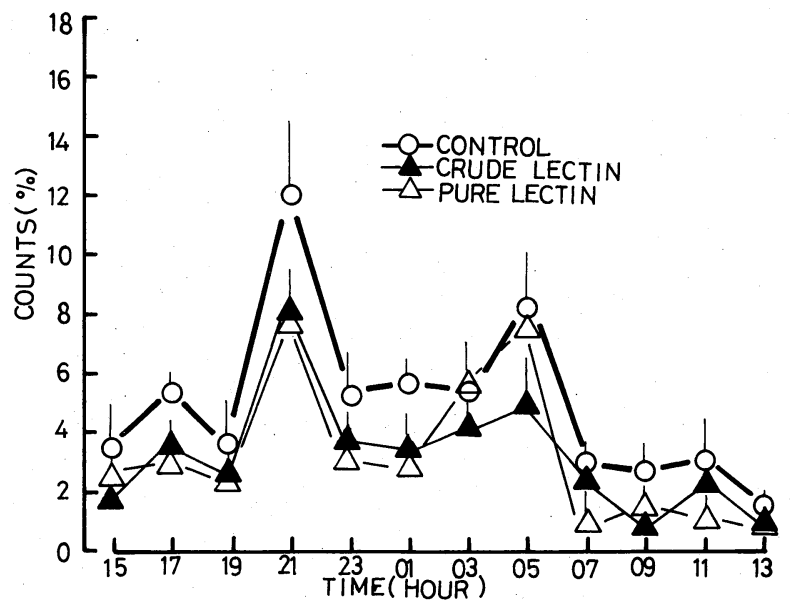

Fig. 1. Physical activity of mice fed Taro tuber lectins by oral administration. 
Table 2. Effect of Taro tuber lectins on the tissue weight of mice.

\begin{tabular}{lcccc}
\hline $\begin{array}{c}\text { Diet } \\
\text { Tissue }\end{array}$ & Control & $\begin{array}{c}\text { Autoclaved } \\
\text { lectin }(100 \mathrm{mg})\end{array}$ & $\begin{array}{c}\text { Crude } \\
\text { lectin }(100 \mathrm{mg})\end{array}$ & $\begin{array}{c}\text { Pure } \\
\text { lectin }(30 \mathrm{mg})\end{array}$ \\
\hline Liver & $6.98 \pm 0.078$ & $7.01 \pm 0.145$ & $7.05 \pm 0.148$ & $6.95 \pm 0.091$ \\
Kidney & $2.01 \pm 0.124$ & $1.99 \pm 0.175$ & $1.95 \pm 0.158$ & $1.98 \pm 0.235$ \\
Spleen & $0.45 \pm 0.041$ & $0.44 \pm 0.021$ & $0.38 \pm 0.014$ & $0.39 \pm 0.043$ \\
Lung & $0.85 \pm 0.105$ & $0.86 \pm 0.072$ & $0.86 \pm 0.095$ & $0.85 \pm 0.100$ \\
Heart & $0.50 \pm 0.008$ & $0.50 \pm 0.004$ & $0.50 \pm 0.005$ & $0.50 \pm 0.008$ \\
\hline
\end{tabular}

Grams per $100 \mathrm{~g}$ body weight: means $\pm \mathrm{SD}(n=4)$.

but significant amount of the lectin possibly penetrated into the blood stream and revealed a direct toxic action on erythrocytes, leading to poor supply of oxygen to the whole body (7). From this point of view concerning the appearance of the toxicity of lectin, the reduction in the physical activity observed in the present experimental mice can be easily understood.

Table 2 shows the tissue weights per $100 \mathrm{~g}$ body weight of the control and experimental mice. When the crude or pure lectin was orally administered, no such changes were observed as expanded spleen, congestion, and color changes in tissues, which are usually found in the case of intraperitoneal injection of lectins. There were also no obvious differences in the tissue weight. Only the weight of spleen slightly decreased in the experimental groups.

Moon described that intestinal villus cells have digestive and absorptive functions (20). It was reported that a winged bean diet lowered intestinal sucrase activity and a raw field bean diet accelerated guanidinoacetate methyltransferase activity and thereby the protein catabolism in the liver $(21,22)$. Deren et al. reported that the activities of intestinal sucrase and LAPse in rats responded to variation in dietary contents (23). In this experiment, activities of three enzymes solubilized in the absence of EDTA were measured to check functional disturbance due to the presence of lectin in the brush border membrane. The results of the measurement of the three enzyme activities are shown in Table 3. The enzyme activities are expressed in terms of micromoles of substrate split in $1 \mathrm{~min}$ by either $1 \mathrm{mg}$ protein or $15 \mathrm{~cm}$ segment of mouse small intestine. The enzyme activities per both $\mathrm{mg}$ protein and $15 \mathrm{~cm}$ segment of the experimental mice were generally lower than those of the control mice regardless of the type of enzyme. The specific activities of alkaline phosphatase, sucrase, and LAPse were 69.1, 70.7, and 74.2\% in the $0-15 \mathrm{~cm}$ intestine, and $69.4,69.8$, and $83.0 \%$ in the $15-30 \mathrm{~cm}$ intestine of the mice of the crude lectin group, respectively, compared with those of the control group. They were $77.6,95.7$, and $76.1 \%$, and $88.6,95.8$, and $90.7 \%$, respectively, in the pure lectin group. There were statistically significant differences between the control and experimental groups in the total activity of alkaline phosphatase but not in the total activities of sucrase and LAPse.

In the present study, most of the activities of these three enzymes were 
Table 3. Effect of Taro tuber lectins on the intestinal enzyme activities.

\begin{tabular}{|c|c|c|c|c|c|}
\hline \multirow{2}{*}{\multicolumn{2}{|c|}{$\begin{array}{l}\text { Enzyme \& Segment } \\
\text { of intestine }\end{array}$}} & Control & Crude lectin & Control & Pure lectin \\
\hline & & \multicolumn{2}{|c|}{$(100 \mathrm{mg} /$ day $)$} & \multicolumn{2}{|c|}{$(30 \mathrm{mg} /$ day $)$} \\
\hline \multicolumn{6}{|c|}{ Alkaline phosphatase $\left(\times 10^{-2}\right)$} \\
\hline \multirow[t]{2}{*}{$\mathrm{U} / \mathrm{mg}$ protein } & $0-15 \mathrm{~cm}$ & $27.51 \pm 4.44$ & $19.01 \pm 2.02 *$ & $26.18 \pm 3.82$ & $20.32 \pm 3.13 *$ \\
\hline & $15-30$ & $25.51 \pm 5.54$ & $17.71 \pm$ & $24.89 \pm 5.22$ & $22.06 \pm 3.33 *$ \\
\hline \multirow[t]{2}{*}{$\mathrm{U} /$ segment } & $0-15 \mathrm{~cm}$ & $1626 \pm 262$ & $1152 \pm 123^{*}$ & $1427 \pm 208$ & $1059 \pm 163^{*}$ \\
\hline & $15-30$ & $1434 \pm 311$ & 1107 & $1332 \pm 279$ & $170^{*}$ \\
\hline \multicolumn{6}{|c|}{ Sucrase $\left(\times 10^{-3}\right)$} \\
\hline \multirow[t]{2}{*}{$\mathrm{U} / \mathrm{mg}$ protein } & $0-1$ & $4.84 \pm 0.86$ & $3.42 \pm 0.74^{*}$ & $4.45 \pm 0.65$ & $4.26 \pm 0.91$ \\
\hline & $15-3$ & $4.44 \pm 1.61$ & $3.10 \pm 1$ & $4.53 \pm 1.43$ & $4.34 \pm 0.86$ \\
\hline \multirow{2}{*}{$\mathrm{U} /$ segment } & $0-15 \mathrm{~cm}$ & $253.6 \pm 45.1$ & $200.1 \pm 43.3$ & $224.7 \pm 32.8$ & $214.7 \pm 45.9$ \\
\hline & $15-30$ & $198.9 \pm 72.1$ & $178.9 \pm 70.7$ & $253.7 \pm 80.1$ & $234.8 \pm 46.5$ \\
\hline \multicolumn{6}{|c|}{ Leucine aminopeptidase $\left(\times 10^{-3}\right)$} \\
\hline \multirow[t]{2}{*}{$\mathrm{U} / \mathrm{mg}$ protein } & $0-15 \mathrm{~cm}$ & $8.46 \pm 2.79$ & $6.28 \pm 1.81$ & $8.17 \pm 1.09$ & $6.22 \pm 1.70$ \\
\hline & $15-30$ & $7.54 \pm 1.68$ & $6.26 \pm 1.67$ & $7.53 \pm 2.63$ & $6.83 \pm 1.89$ \\
\hline \multirow[t]{2}{*}{ U/segment } & $0-15 \mathrm{~cm}$ & $494.9 \pm 163.2$ & $352.9 \pm 101.7$ & $393.0 \pm 52.4$ & $311.6 \pm 85.2$ \\
\hline & $15-30$ & $398.9 \pm 88.9$ & $343.7 \pm 91.7$ & $409.6 \pm 143.1$ & $359.9 \pm 99.6$ \\
\hline
\end{tabular}

Means \pm SD $(n=4)$. * Significantly different from each control group, $p<0.05$. "U" means micromoles of each substrate split per min.

recovered in the supernatant solutions of intesine homogenates in which brush border membranes were considered to have been disintegrated into microsome-like particles as described by Miller and Crane (14). Therefore, the activities in the solubilized fractions are considered to represent tendencies in activity of these enzymes in the intestine, although it seems preferable to compare whole activities including the residual activity in the sediments. Significant decreases in the activity of sucrase, alkaline phosphatase, and LAPse in the small intestine were also reported in the rats fed for 4 days on a diet containing $30 \%$ raw winged bean (21). Higuchi et al. reported that HA was detected in the intestinal mucosa and feces of the rats which had ingested winged bean lectin resistant to digestive enzymes (24). The reason for the smaller extent of enzyme inhibition by Taro tuber lectin seems to lie in the fact that Taro tuber lectin is more susceptible to proteases in the digestive organs than legume lectins as reported previously (10).

The antinutritional effects of orally ingested Taro tuber lectin were observed in the present experiment as the reductions in the body weight, food intake, PER, physical activity, and intestinal enzyme activities. Although the discrete mode of the toxic action of the lectin is not completely understood at present, it is considered that inhibition of nutrient absorption is surely brought about as a result of the decline in the intestinal enzyme activity. From these results, we concluded that the lectin present in Taro tuber is a major factor in the toxicity found on ingestion of Taro tuber, although the toxicity is not so high as that of bean lectins. Our previous study indicated that most of the hamagglutinating activity in Taro tuber heated at 
$100^{\circ} \mathrm{C}$ for $20 \mathrm{~min}$ was retained. Therefore, Taro tuber lectin, despite its weaker toxicity, deserves more attention. It is necessary, for instance, to look further into the mechanism of growth inhibitory effects on mice of Taro tuber lectin fed ad libitum by examining the binding of the lectin to intestine and subsequent morphological changes on intestinal tissues.

\section{REFERENCES}

1) Goldstein, I. J. (1982): Carbohydrate-binding proteins in search of a function, in Food Carbohydrates, ed. by Lineback, D. R., and Inglett, G. E., AVI Publishing Co., Westport CT, pp. 206-216.

2) Goldstein, I. J., and Hayes, C. E. (1978): Carbohydrate-binding proteins of plant and animals, in Carbohydrate Chemistry and Biochemistry, ed. by Tipson, R. T., and Horton, D., Academic Press, New York, pp. 127-340.

3) Lis, H., and Sharon, N. (1981): Lectins in higher plants, in The Biochemistry of Plants, ed. by Marcus, A., Academic Press, New York, pp. 371-448.

4) Liener, I. E. (1986): Nutritional significance of lectins in the diet, in The Lectins Functions and Applications in Biology and Medicine, ed. by Liener, I. E., Sharon, N., and Goldstein, I. J., Academic Press, New York, pp. 527-552.

5) King, T. P., Pusztai, A., and Clarke, E. M. W. (1982): Kidney bean (Phaseolus vulgaris) lectin-induced lesions in rat small intestine. 3. Ultrastructural studies. $J$. Comp. Pathol., 92, 357-373.

6) Sjolander, A., Magnusson, K. E., and Latkovic, S. (1984): The effect of concanavalin $A$ and wheat germ agglutinin on the ultrastructure and permeability of rat intestine. A possible model for an intestinal allergic reaction. Int. Arch. Allergy Appl. Immunol., 75, 230-236.

7) Pusztai, A., Clarke, E. M. W., Grant, G., and King, T. P. (1981): The toxicity of Phaseolus vulgaris lectins. Nitrogen balance and immunochemical studies. J. Sci. Food Agric., 32, 1037-1047.

8) Hara, T., Tsukamoto, I., and Miyoshi, M. (1983): Oral toxicity of Kintoki bean (Phaseolus vulgaris) lectin. J. Nutr. Sci. Vitaminol., 29, 586-599.

9) Grant, J., More, L. J., McKenzie, N. H., Stewart, J. C., and Pusztai, A. (1983): A survey of the nutritional and hemagglutination properties of legume seeds generally available in the UK. Brit. J. Nutr., 50, 207.

10) Seo, Y. J., Kamitani, S., Tsukamoto, I., and Miyoshi, M. (1989): Heat resistance of Taro tuber (Colocasia antiquorum) lectin and changes in its contents during germination. Nippon Kasei Gakkaishi (J. Home. Econ. Jpn.), 40, 805-809.

11) Kamitani, S., Seo, Y., Tsukamoto, I., and Miyoshi, M. (1987): Purification and some properties of Taro tuber (Colocasia antiquorum Schott) lectin. Nippon Kasei Gakkaishi (J. Home Econ. Jpn. ), 38, 455-464.

12) Jaffé, W. G. (1960): Über Phytotoxin aus Bohnen (Phaseolus vulgaris). Arzneimittel Forsch., 10, 101.

13) Holt, J. H., and Miller, D. (1962): The localization of phosphomonoesterase and aminopeptidase in brush border of isolated intestinal epithelial cells. Biochim. Biophys. Acta, 58, 239-243.

14) Miller, D., and Crane, R. K. (1961): The digestive function of the epithelium of the 
small intestine. II. Localization of disaccharide hydrolysis in the isolated brush border portion of intestinal epithelial cells. Biochim. Biophys. Acta, 52, 293-298.

15) Lowry, O. H., Rosebrough, N. J., Farr, A. L., and Randall, R. L. (1951): Protein measurement with the Folin phenol reagent. J. Biol. Chem., 193, 265-275.

16) Kind, P. R. N., and King, E. J. (1951): Estimation of plasma phosphatase by determination of hydrolyzed phenol with aminoantipyrine. J. Clin. Pathol., 7, 322-326.

17) Dahlquvist, A. (1964): Method for assay of intestinal disaccharides. Anal. Biochem., 7, 18-25.

18) Goldbarg, J. A., and Rutenburg, A. M. (1958): The colorimetric determination of leucine aminopeptidase in urine and serum of normal subject and patient with the cancer and other disease. Cancer, 11, 283-391.

19) Snedector, G. W., and Cochran, W. G. (1976): Statistical Methods, Iowa State University Press.

20) Moon, H. W. (1978): Mechanisms in the pathogenesis of diarrhea. J. Am. Veter. Med. Assoc., 172, 443-448.

21) Kimura, T., Satanachote, C., and Yoshida, A. (1982): Effects of feeding of raw winged bean seeds on gastrointestinal function in rats. J. Nutr. Sci. Vitaminol., 28, 27-33.

22) Santidrian, S., Sobrini, F. J., Billo, J., and Iarralde, J. (1981): Guanidinoacetate methyltransferase activity in growing male rat fed on a raw field bean (Vicis faba L.) diet. Enzyme, 26, 103-106.

23) Deren, J. J., Broitman, S. A., and Zamcheck, N. (1967): Effect of diet upon intestinal disaccharidase and disaccharide absorption. J. Clin. Invest., 46, 186-195.

24) Higuchi, M., Suga, M., and Iwai, K. (1983): Participation of lectin in biological effects of winged bean. Agric. Biol. Chem., 47, 1879-1886. 